\title{
Normalizing action of exendin-4 and GLP-1 in the glucose metabolism of extrapancreatic tissues in insulin-resistant and type 2 diabetic states
}

\author{
Paola Moreno ${ }^{1,2}$, Bernardo Nuche-Berenguer ${ }^{1,2}$, Irene Gutiérrez-Rojas ${ }^{1,2}$, Alicia Acitores ${ }^{1,2}$, \\ Verónica Sancho ${ }^{1}$, Isabel Valverde ${ }^{1,2}$, Nieves González ${ }^{1,2 \star}$ and \\ María L Villanueva-Peñacarrillo ${ }^{1,2 *}$ \\ ${ }^{1}$ Department of Metabolism, Nutrition and Hormones, IIS-Fundación Jiménez Díaz, Avda. Reyes Católicos, 2, 28040 Madrid, Spain \\ ${ }^{2}$ CIBERDEM, Madrid, Spain \\ (Correspondence should be addressed to N González; Email: ngonzalezg @ fjd.es) \\ *(N González and M L Villanueva-Peñacarrillo have the same senior status)
}

\begin{abstract}
Exendin-4 (Ex-4) mimics glucagon-like peptide-1 (GLP-1 or GCG as listed in the HUGO database), being anti-diabetic and anorectic, in stimulating glucose and lipid metabolism in extrapancreatic tissues. We studied the characteristics of Ex-4 and GLP-1 action, during prolonged treatment, on GLUTs expression (mRNA and protein), glycogen content (GC), glucose transport (GT), glycogen synthase a (GSa), and kinase (PI3K and MAPKs) activity, in liver, muscle, and fat of insulin-resistant (IR, by fructose) and type 2 diabetic (T2D, streptozotocin at birth) rats compared with normal rats. In both IR and T2D, the three tissues studied presented alterations in all measured parameters. In liver, GLP-1 and also Ex-4 normalized the lower than normal Glut2 (S/c2a2) expression and showed a trend to normalize the reduced GC in IR, and GLP-1, like Ex-4, also in T2D, effects mediated by PI3K and MAPKs. In skeletal muscle, neither GLP-1 nor Ex-4 modified Glut4 (S/c2a4) expression in either experimental model but showed normalization of reduced GT and GSa, in parallel with the normalization of reduced PI3K activity in T2D and MAPKs in both models. In adipose tissue, the altered GLUT4 expression in IR and T2D, along with reduced GT in IR and increased GT in T2D, and with hyperactivated PI3K in both, became normal after GLP-1 and Ex-4 treatment; yet, MAPKs, that were also higher, became normal only after Ex-4 treatment. The data shows that Ex-4, as well as GLP-1, exerts a normalizing effect on IR and T2D states through a distinct post-receptor mechanism, the liver being the main target for Ex-4 and GLP-1 to control glucose homeostasis.
\end{abstract}

Journal of Molecular Endocrinology (2012) 48, 37-47

\section{Introduction}

Insulin resistance (IR) leads to hypertension, cardiovascular disease, dyslipidemia, and type 2 diabetes (T2D; Hotamisligil 2000, Zierath et al. 2000); it is also associated with obesity and hyperinsulinemia.

Glucagon-like peptide-1 (GLP-1 or GCG as listed in the HUGO database), an incretin hormone with antidiabetic properties, exerts insulin-like effects upon glucose transport (GT) and metabolism in the liver, skeletal muscle, and fat of humans and rats (Valverde et al. 1994, Villanueva-Peñacarrillo et al. 1994, 2001, Sancho et al. 2005), tissues where its effects are dependent on protein kinase (Redondo et al. 2003, Acitores et al. 2004, Sancho et al. 2005). The regulatory action of GLP-1 in glucose and lipid metabolism in the liver, muscle, and fat in normal and T2D situations is, out of doubt, due to its neurotrophic and cardioprotective properties (Ossum et al. 2009, Bak et al. 2011). In addition, a recent study has shown that in mesenchymal cells, GLP-1 promotes cellular proliferation and cytoprotection and prevents cell differentiation into adipocytes (Sanz et al. 2010).

Exendin 1-39 amide (Ex-4), a naturally occurring non-mammalian (Chen \& Drucker 1997) peptide that has partial sequence homology with GLP-1 (Eng et al. 1992), has several similar glucoregulatory effects on mammals as GLP-1; however, Ex-4 has a much longer circulating half-life than GLP-1 - it is resistant to degradation by dipeptidyl peptidase IV - which makes it suitable as an anti-diabetic agent (Nielsen et al. 2004); in fact, as such it is being used either alone or in combination with oral anti-diabetic drugs (Fineman et al. 2003).

Ex-4 mimics GLP-1 in stimulating GT and metabolism in rat liver, skeletal muscle and fat, in an insulinindependent manner (Alcántara et al. 1997, Morales et al. 1997, Sancho et al. 2005), as well as lipogenesis and lipolysis in the latter cells (Sancho et al. 2005). In rat muscles, Ex-4, like GLP-1 (Villanueva-Peñacarrillo et al. 2001), stimulates the in vivo expression of corresponding major glucotransporter in normal and T2D states 
(Arnés et al. 2009). Similar to GLP-1 (Willms et al. 1996), Ex-4 lowers gastric emptying (Talsania et al. 2005) due to its anorectic properties (Barrera et al. 2009). The reported effects of Ex-4 on extrapancreatic tissues are dependent on an increase in the activity of several kinases (González et al. 2005a, Sancho et al. 2005, Arnés et al. 2008), some of them are also involved in GLP-1 and insulin actions (Acitores et al. 2004, González et al. $2005 a$, Sancho et al. 2005). The GLP-1-like glucoregulatory actions of Ex-4 (Nielsen et al. 2004) are thought to be exerted, at least in part, not only through the pancreatic GLP-1 receptor (Tourrel et al. 2002) but also by interacting with GLP-1 receptors in the liver and muscle (Delgado et al. 1995, Villanueva-Peñacarrillo et al. 1995, Arnés et al. 2008), which seem to be structurally and/or functionally distinct from that in the pancreas (Thorens 1992). Thus, in the former tissues, neither GLP-1 nor Ex-4 increases cAMP content, although both stimulate inositol phosphoglycan production (Villanueva-Peñacarrillo et al. 1994, Alcántara et al. 1997, Luque et al. 2002).

Very recently, an osteogenic effect of GLP-1 and also Ex-4 has been noted in three experimental rat models, IR, T2D, and hyperlipidemic where both peptides promote toward normalization, bone formation (Nuche-Berenguer et al. 2009, 2010a,b, 2011), and action of GLP-1 that has been proposed to occur through a specific receptor (Nuche-Berenguer et al. 2010a,b) other than the pancreatic cAMP-associated GLP-1 receptor.

At present, little is known about the effect of a sustained action of GLP-1 on the glucose metabolism in the main tissues participating in the hexose homeostasis in the IR state, similar to that of Ex-4 in the same situation of altered insulin secretion and also in diabetes. Here, we have studied the possible in vivo modulating effect of both Ex-4 and GLP-1, during prolonged treatment, on the characteristics of parameters related to the liver, muscle, and fat/glucose uptake and metabolism, in an IR and in a T2D model, compared with the normal state.

\section{Materials and methods}

\section{Reagents}

Human GLP-1 (7-36) amide (GLP-1) and exendin (1-39) amide (Ex-4) were purchased from Bachem AG (Bubendorf, Switzerland); rat insulin was purchased from Linco (St Charles, MO, USA) and pork insulin from Novo Biolabs (Bagsvaerd, Denmark); streptozotocin from Sigma-Aldrich; Alzet 1003D osmotic pumps from Alza (Palo Alto, CA, USA); Rainbow markers and ECL-Western blotting kit and Hyperfilm ECL were from Amersham Pharmacia Biotech; glucose reagents from Beckman Instruments, Inc. (Palo Alto, CA, USA); collagenase P of
Clostridium histolyticum from Roche Diagnostics; transfer semidry system from Trans-blot SD semidry transfer cell, Bio-Rad; TRI REAGENT for RNA isolation from SigmaAldrich Química S.A.; Taqman Universal PCR master mix and high-capacity cDNA reverse transcription kit, probes and primers for rat Glut2 (Rn00563565_m1), Glut4 (Rn00562597_m1), eukaryotic 18s (4319413E), and glyceraldehyde-3-phosphate dehydrogenase (Gapdh, 4331182) were from Applied Biosystems (Woolston, Warrington Cheshire, UK); mouse anti-total, rabbit anti-total, and anti-phosphorylated form of p44/42MAP kinase were from Cell Signalling Technology (New England Biolabs, Beverly, MA, USA); rabbit anti-PI3kinase p85 from Upstate Biotechnology (Lake Placid, $\mathrm{NY}, \mathrm{USA})$; 2-deoxy-D-[1,2- $\left.{ }^{3} \mathrm{H}(\mathrm{N})\right]$ glucose $(40 \mathrm{Ci} / \mathrm{mmol})$ from Moravek Biochemicals (Brea, CA, USA); [U- $\left.{ }^{14} \mathrm{C}\right]$ sorbitol $(320 \mathrm{mCi} / \mathrm{mmol})$ from American Radiolabeled Chemicals, Inc. (St Louis, MO, USA); UDP- $\left[{ }^{14} \mathrm{C}\right] \mathrm{D}$-glucose $(302 \mathrm{mCi} / \mathrm{nmol})$ from PerkinElmer (Boston, MA 02118, USA); $\left[\gamma^{32} \mathrm{P}\right]$ ATP $(30 \mathrm{Ci} /$ nmol) and Ultima Gold scintillation liquid were from Packard (Gröninger, The Netherlands). All other commonly used chemicals, unless otherwise stated, were purchased from Sigma-Aldrich Química or Merck Pharma Quimica.

\section{Animals}

Male Wistar rats, maintained on a standard pellet diet (UAR Panlab, Barcelona, Spain) and tap water made available ad libitum, were used. The IR model was prepared in normal rats by chronic feeding standard chow combined with D-fructose dissolved in drinking water at $20 \%$ concentration (Cancelas et al. 2008) for 8 weeks. The T2D model was obtained in normal rats by a single dose of streptozotocin dissolved in $0.9 \% \mathrm{NaCl}$ saline $(100 \mu \mathrm{g} / \mathrm{g}$ of body weight), intraperitoneally administered on the day of birth (Portha et al. 1979, Iwase $e t$ al. 1987); at the age of 8 weeks, those rats showing a glucose disappearance constant $(\mathrm{K})$ below $2.5 \times 10^{-2}$, min after an i.v. glucose tolerance test $(0.05 \mathrm{mg}$ glucose $/ \mathrm{g}$ of body weight in $30 \mathrm{~s}$ ) were selected. All rats belonging to the same three groups were of the same age (12-13 weeks old) by the time applying the experimental protocol of the study. Animal housing and protocols were approved by the Animal Use Committee of the Fundación Jiménez Díaz, Madrid, Spain.

\section{Experimental design}

Normal (N), IR, and T2D rats were subjected to a 3-day treatment (Villanueva-Peñacarrillo et al. 2001, Arnés et al. 2008) with GLP-1 and Ex-4 at a dose of 0.86 and $0.1 \mathrm{nmol} / \mathrm{kg}$ per $\mathrm{h}$ respectively, dissolved in saline solution, by continuous infusion through 
a subcutaneously implanted osmotic pump. Treatment of rats from the three groups was initiated at $0900 \mathrm{~h}$. As respective control, rats of the three groups were treated only with saline solution. Just before and after the treatment $(72 \mathrm{~h})$, blood samples were collected from all rats in fed condition for plasma glucose and insulin determinations; afterwards, the animals were stunned and killed by a sharp blow to the head, and soleus muscles, epididymal fat pads, and liver of the animals, quick-frozen at $-70{ }^{\circ} \mathrm{C}$, were used to prepare solubilized membranes (Villanueva-Peñacarrillo et al. 2001) for the analysis of major respective glucotransporter gene expression and the activity of cell signaling enzymes (Villanueva-Peñacarrillo et al. 2001, Redondo et al. 2003, Acitores et al. 2004, Sancho et al. 2005); additionally, the liver glycogen content (GC) was measured by the anthrone method (Chun and Yin 1998), the soleus muscle glycogen synthase $a(\mathrm{GS} a)$ activity as described previously by Luque et al. (2002) and glucose transport and the isolated adipocytes glucose uptake by Sancho et al. (2005).

\section{Plasma measurements}

Glucose was measured by the glucose oxidase method (Glucose analyzer 2; Beckman, Galway, Ireland), and insulin was measured by RIA (Herbert et al. 1956) using rat insulin as a standard and guinea pig serum antiinsulin (GP-25) that was developed in our laboratory (Valverde et al. 1988).

\section{Glucose transport}

The soleus muscles in rats were individually attached by the tendon to a steel clip (Valverde et al. 1994) and were incubated in the absence of added peptides (control), for $60 \mathrm{~min}$ at $37^{\circ} \mathrm{C}$, in $3 \mathrm{ml}$ Krebs-Henseleit (KH) buffer containing $15 \mu \mathrm{mol}$ 2-deoxy-D-[1,2- $\left.{ }^{3} \mathrm{H}(\mathrm{N})\right]$ glucose (Sp. Act: $40 \mathrm{nCi} / \mu \mathrm{mol}$ ) and $60 \mu \mathrm{mol}\left[\mathrm{U}_{-}{ }^{14} \mathrm{C}\right]$ sorbitol (Sp. Act: $5 \mathrm{nCi} / \mu \mathrm{mol}$ ) 5 and $20 \mathrm{mM}$ in the incubation media. During the incubation period, an atmosphere of $\mathrm{O}_{2} / \mathrm{CO}_{2}(95 / 5)$ was maintained in the vials sealed with a rubber stopper. After, the extracellular radioactivity was removed by quick washing at $4{ }^{\circ} \mathrm{C}$ in $\mathrm{KH}$, the muscle was treated with $1 \mathrm{ml} 1 \mathrm{M} \mathrm{NaOH}$ for $10 \mathrm{~min}$ at $70^{\circ} \mathrm{C}$. The solubilized product was placed in $5 \mathrm{ml}$ scintillation liquid for determining the ${ }^{3} \mathrm{H}$ and ${ }^{14} \mathrm{C}$ content by double channel counting; an aliquot volume $(2 \mu \mathrm{l})$ had previously been taken from all solubilized samples for the measurement of total protein (Bradford 1976). To calculate the cellular D-glucose uptake in each muscle sample $(\mathrm{pmol} / \mathrm{mg}$ protein per $\mathrm{min})$, the total 2-deoxy-D-[1,2- $\left.{ }^{3} \mathrm{H}\right]$ glucose accumulated was corrected taking into account the extracellular space, as determined by the $\left[{ }^{14} \mathrm{C}\right]$ sorbitol uptake value, following a method previously described in Dohm et al. (1988).

Adipocytes were isolated at $37^{\circ} \mathrm{C}$ by enzymatic digestion with collagenase $\mathrm{P}$ from the rat epididymal fat pads (Rodbell 1964). Then, cells $\left(10^{5}\right)$ were incubated for $15 \mathrm{~min}$ at $37^{\circ} \mathrm{C}$ in $400 \mu \mathrm{KRB}, 10.9 \mathrm{mM}$ HEPES, $500 \mathrm{U} / \mathrm{ml}$ Trasylol, and $2 \%$ BSA, pH $7 \cdot 4$. This was followed by a $3 \mathrm{~min}$ incubation in the additional presence of $0.26 \mu \mathrm{Ci}(6.5 \mathrm{pmol}) 2$-deoxy-D$\left[1,2-{ }^{3} \mathrm{H}(\mathrm{N})\right]$ glucose (final concentration $16 \cdot 3 \mathrm{nM}$ 2-DOG). Adipocytes, after being separated at $7200 \mathrm{~g}$ in $100 \mu \mathrm{l}$ dioctyl phthalate, were added to $3 \mathrm{ml}$ scintillation liquid for $\beta$-counting. The total D-glucose content was corrected for the unspecific D-glucose uptake value, obtained in cell samples from each experiment treated in parallel with $0.175 \mathrm{mM}$ cytochalasin B (Perea et al. 1997).

\section{GSa activity}

The soleus muscle samples were homogenized in a medium containing $100 \mathrm{mM}$ Nave, $35 \mathrm{mM}$ EDTA, $50 \mathrm{mM}$ glycylglycine, and $0.5 \%$ glycogen $(\mathrm{w} / \mathrm{v})$ at $\mathrm{pH}$ $7 \cdot 4$, as already described in Villanueva-Peñacarrillo $e t a l$. (1994), and maintained at $-70{ }^{\circ} \mathrm{C}$ until their enzymatic activity was analyzed. The frozen tissue homogenates were thawed at $4{ }^{\circ} \mathrm{C}$, and the enzymatic activity was analyzed, at least in duplicate, by the incorporation of UDP- $\left[{ }^{14} \mathrm{C}\right] \mathrm{D}$-glucose into glycogen, for $15 \mathrm{~min}$, as previously described in detail in Villanueva-Peñacarrillo et al. (1994). For each experimental rat, the mean value of the replicates corresponding to the muscles of rats treated with saline was used as the control value.

\section{Isolation of total RNA and real-time PCR}

Total RNA was extracted from the muscle, fat, and liver by the TRI REAGENT isolation method, according to the manufacturer's protocol. Total RNA concentration and purity were estimated spectrophotometrically from the absorption at 260 and $280 \mathrm{~nm}$ respectively, in an aliquot volume of each sample (Arnés et al. 2008). For quantitative real-time PCR, the first-strand cDNA was synthesized from $4 \mu \mathrm{g}$ total RNA using the High-Capacity cDNA Reverse Transcription Kit. Samples were subjected to quantitative amplification using the TaqMan probe and primer sets for rat Glut4 (Slc2a4) and Glut2 (Slc2a2) PCR amplification was carried out in triplicate for each sample and was performed in a total volume of $20 \mu \mathrm{l}$ containing $400 \mathrm{ng}$ cDNA, $900 \mathrm{nM}$ each primer, $500 \mathrm{nM}$ of the respective probe, and $10 \mu \mathrm{l}$ TaqMan Master Mix. The conditions for amplification and detection - 40 cycles/110 min were described in Ascencio et al. (2004). For each rat, gene expression was normalized with that of the housekeeping gene $18 S$ or Gapdh and expressed as $2^{-\Delta \Delta C_{\mathrm{t}}}$. 


\section{Kinase activity}

Tissue samples were homogenized at $4{ }^{\circ} \mathrm{C}$ in $1.25 \%$ Triton X-100 containing $250 \mathrm{mM}$ sucrose, $20 \mathrm{mM}$ Tris/HCl, $2.5 \mathrm{mM} \mathrm{MgCl}_{2}, 50 \mathrm{mM} \beta$-mercaptoethanol, $1.2 \mathrm{mM}$ EGTA, $1 \mathrm{mM} \mathrm{Na} \mathrm{VO}_{4}, 5 \mathrm{mM} \mathrm{Na} \mathrm{P}_{2} \mathrm{O}_{7}, 50 \mathrm{mM} \mathrm{NaF}$, $2 \mu \mathrm{M}$ leupeptin, $2 \mu \mathrm{M}$ pepstatin, $\mathrm{pH} 7 \cdot 4$, and $2 \mathrm{mM}$ PMSF, then maintained at $4{ }^{\circ} \mathrm{C}$ for $30 \mathrm{~min}$, and finally centrifuged at $15000 \mathrm{~g}$ (Dohm et al. 1988). The supernatant (tissue lysate), containing cytosol and solubilized membranes, was kept at $-70^{\circ} \mathrm{C}$ until needed. An aliquot volume was taken from all tissue lysate samples for determining the protein content (Valverde et al. 1988). MAP kinase activity ( $p$-p $44 / p$-p 42$)$ was measured by immunoblotting (Redondo et al. 2003, Acitores et al. 2004, and Sancho et al. 2005). PI3K activity was measured directly in $\mathrm{p} 85$ immunoprecipitates obtained by treating the muscle, fat, and liver lysates with anti-PI3 kinase p85 and subsequent coupling to protein A-agarose (Phung et al. 1997, Redondo et al. 2003, Acitores et al. 2004, Sancho et al. 2005); the immunoprecipitates were incubated for $20 \mathrm{~min}$ at room temperature with $20 \mu \mathrm{M}\left[\gamma^{32} \mathrm{ATP}\right]$ ( $5 \mu \mathrm{Ci} / \mathrm{nmol}$ ) containing $6.25 \mathrm{mM}$ HEPES, $5 \mathrm{mM} \mathrm{MgCl}$, and $0.25 \mathrm{mM}$ EGTA, and in the presence of $0.25 \mathrm{mg} / \mathrm{ml}$ phosphatidylinositol/phosphatidylserine as a substrate; the reaction was interrupted by addition of $400 \mu \mathrm{l}$ chloroform/methanol/HCl (1:2:1, v/v), $150 \mu \mathrm{l}$ chloroform, and $150 \mu \mathrm{l} \mathrm{HCl}$. After centrifugation $(10000 \mathrm{~g}$ ), the organic phase was treated with an equal volume of methanol/100 mM HCl/2.5 mM EDTA (1:1:1, v/v), and the new organic phase was separated by centrifugation and speed-vac dried. The lipidic extract, redissolved in chloroform, was spotted, together with $\mathrm{PIP}_{3}$ standard, on a silica gel TLC plate and developed in $n$-propanol/ acetic acid $/ \mathrm{H}_{2} \mathrm{O}(66: 2: 33$, v/v). Plates were dried, and radioactive $\mathrm{PIP}_{3}$ was subsequently visualized by autoradiography and analyzed by densitometric scanning.

\section{Immunoblotting}

Equal amounts of tissue lysate from each sample were subjected to SDS-PAGE (Laemmli 1970), in parallel with molecular weight markers, on an $8 \%$ resolving gel; the separated proteins were then transferred to a nitrocellulose membrane in a semidry system (Transblot SD semidry transfer cell, Bio-Rad). For immunodetection, a western blotting kit was used following the manufacturer's instructions, using total and phosphorylated p44/42 MAPK antibodies, GLUT2 (for liver), and GLUT4 (for muscle and fat) respective antibodies and anti- $\alpha$-tubulin, and a HRP-conjugated donkey anti-rabbit immunoglobulin secondary antibody, with detection by the enhanced chemiluminescence method and quantization by densitometric scanning of the autoradiography (Villanueva-Peñacarrillo et al. 2001, Redondo et al. 2003, Acitores et al. 2004,
Sancho et al. 2005). The densitometric value of the band corresponding to GLUT2 and GLUT4 protein was normalized, when required, with respect to that of the $\alpha$-tubulin, and the values obtained from the rat treated with saline solution were used as control values.

\section{Statistical analysis}

Results are expressed as mean \pm s.E.M., together with the number of observations. The statistical significance $(P<0 \cdot 05)$ of the increments was assessed by either one-way ANOVA, followed by the least significant differences test for post hoc multiple comparisons, using the Statistical Package for the Social Science (SPSS Inc, Chicago, IL, USA) software, or Student's $t$-test.

\section{Results}

\section{Plasma measurements}

Plasma glucose value in the IR rats $(91 \pm 3 \mathrm{mg} / \mathrm{dl}$, $n=24$ rats) was slightly lower than that of the normal rats $(102 \pm 5 \mathrm{ng} / \mathrm{dl}, n=25)$, whereas higher in the T2D group (141 $\pm 8, n=24 P<0 \cdot 001)$; however, the insulin level in IR was higher $(3.0 \pm 4 \mathrm{mg} / \mathrm{ml}, P<0 \cdot 02)$ than that in $\mathrm{N}(1 \cdot 7 \pm 0 \cdot 2)$, while lower in T2D $(0 \cdot 7 \pm 0 \cdot 1$, $P<0.05$ vs N). No significant differences were observed in either parameter, glucose or insulin, after GLP-1 or Ex-4 treatment. It should be taken into account that the plasma variables were measured in the rats in fed condition, as they had free access to food and water throughout the 3-day experimental period.

\section{Liver GLUT2 expression and GC}

In the IR-control group (Fig. 1), the liver Glut2 mRNA was much lower $(P<0 \cdot 01, n=17$ rats $)$ than that in the $\mathrm{N}$ group, and hence it was the protein $(-44 \pm 8 \% \Delta \mathrm{N}-$ control, $P<0 \cdot 01$ ). Both GLP-1 and Ex-4 increased not only the Glut 2 mRNA (both, $n=5 ; P<0 \cdot 01$ ) to a level even higher than that in the normal group (GLP-1: $2 \cdot 8 \pm 0 \cdot 4$ times $\mathrm{N}-$ control and Ex-4: $4 \cdot 0 \pm 0 \cdot 4$; both $P<0 \cdot 05)$ but also the protein (GLP-1: $147 \pm 18 \%$ N-control; Ex-4: $187 \pm 11 \%$ N-control; both $P<0 \cdot 05$ ).

In the IR-control rats (Fig. 1), GC in the liver (193 $\pm 20 \mu \mathrm{g} / \mathrm{mg}$ protein, $n=8)$ was lower $(P<0 \cdot 01)$ than that in the $\mathrm{N}$ rats $(395 \pm 35 \mu \mathrm{g} / \mathrm{mg}$ protein, $n=6)$, and so it was in T2D rats $(225 \pm 20 \mu \mathrm{g} / \mathrm{mg}$ protein, $n=5 ; P<0 \cdot 01)$, the latter confirming the previous data from our laboratory (Arnés et al. 2009); GLP-1 treatment increased the concentration in the IR group $(295 \pm 14 \mu \mathrm{g} / \mathrm{mg}$ protein, $P<0.01$ vs IR-control, $n=11)$ and also in the T2D rats $(561 \pm 57 \mu \mathrm{g} / \mathrm{mg}, P<0 \cdot 01$ vs T2D-control, $n=5$ ), the value reached in the latter group being even 

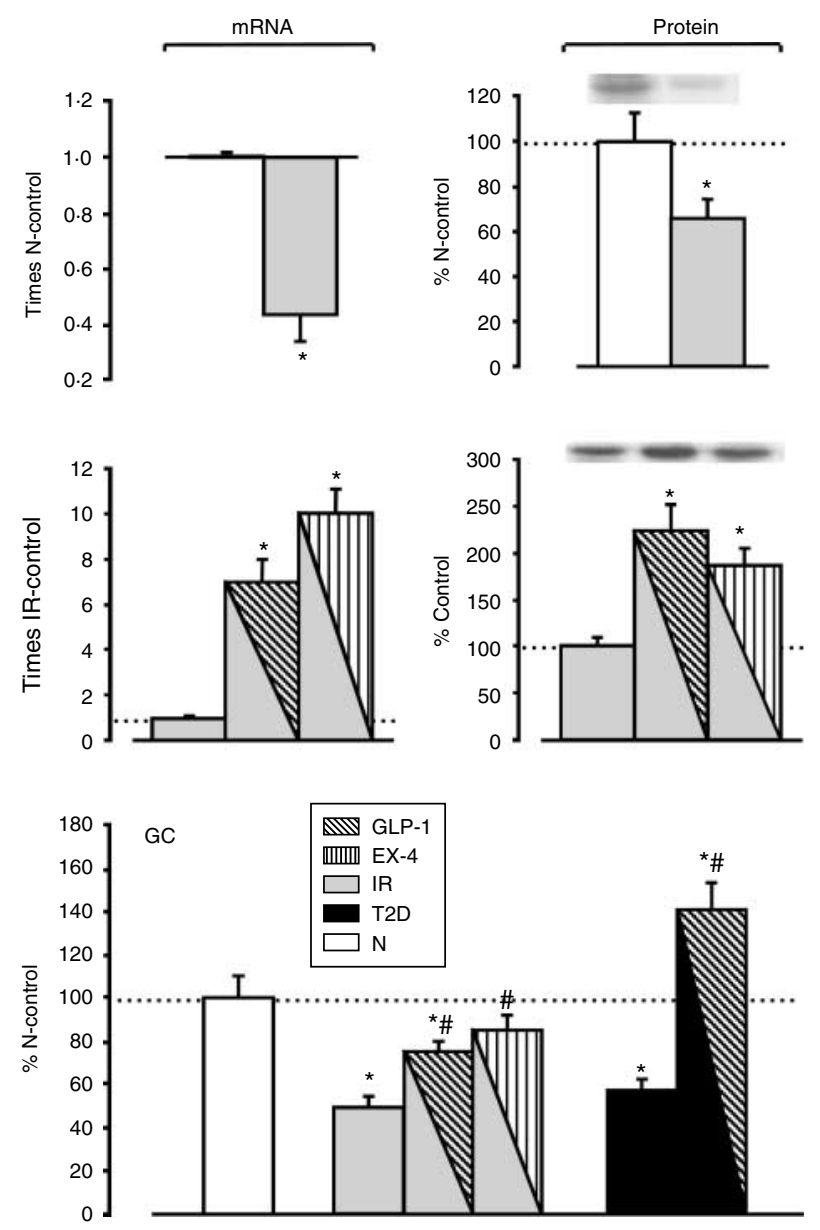

Figure 1 Effect of GLP-1 and Ex-4 treatment on Glut2 expression ( $n=7-15$ rats) and glycogen content (GC, $n=5-12)$ in the liver of insulin-resistant (IR) and type 2 diabetic (T2D) rats. Data (mean \pm s.E.M.) are expressed as relative amounts (Glut2 mRNA) or percentage (GLUT2 protein and $G C$ ) of the normal $(N)$ or respective control group (saline treated). ${ }^{\star} P<0.05$, or lower, vs $\mathrm{N}$-control; ${ }^{\#} P<0.05$, or lower, vs respective control value, IR or T2D.

above $(P<0 \cdot 05)$ than that in the liver of $\mathrm{N}$ rats. Ex-4 also increased the GC in the liver of IR rats to a value (338 \pm $27 \mu \mathrm{g} / \mathrm{mg}$ protein, $n=12 ; P<0.01 \mathrm{vs}$ IR-control) indistinguishable from that in the $\mathrm{N}$ rats. Tables 1 and 2 show the qualitative changes in the abovementioned parameters and correspond to the data contained in Fig. 1; those that are already being published are not shown in the figures but have been included in the tables for comparison.

\section{Muscle GLUT4 expression, GT, and GSa activity}

In IR rats, Glut 4 mRNA ( $P<0.01$ vs N-control; Fig. 2$)$ as well as protein $(143 \pm 39 \% \Delta \mathrm{N}$-control, $n=5$ rats; $P<0 \cdot 05)$ was overexpressed; treatment with both GLP-1 and Ex-4 increased the mRNA even further (both, $n=5$; $P<0 \cdot 001$ vs IR-control) as well as the protein (GLP-1:
$283 \pm 59 \% \Delta$ IR-control, $n=5, P<0 \cdot 01 ;$ Ex-4: $76 \pm 27 \%$ $\Delta, n=5, P<0 \cdot 02)$.

In the skeletal muscle, the net glucose uptake (GT) in the IR group $(0 \cdot 192 \pm 0 \cdot 04 \mathrm{nmol} / \mathrm{mg}$ protein per $\min , n=7)$ was much lower $(P<0.05)$ than that in the $\mathrm{N}$ group $(0 \cdot 418 \pm 0 \cdot 09, n=5)$; a 3-day treatment with GLP-1 increased $(P<0 \cdot 001)$ the value in the IR-control rats $(268 \pm 13 \%, n=10)$ to levels even higher than those in the $\mathrm{N}$-control rats $(P<0 \cdot 001)$, and the same increasing effect was observed by Ex-4 $(392 \pm 9 \%$ IRcontrol, $n=10 ; P<0 \cdot 001)$, although to a higher $(P<0 \cdot 001)$ extent than that by GLP-1. In T2D rats, GT in the muscle was indistinguishable from that in $\mathrm{N}$ rats, confirming the previous results (Arnés et al. 2009); this GT value was not altered after GLP-1 treatment, in comparison with the previous observations on Ex-4 treatment in the skeletal muscle of this same experimental diabetic model, by which an increase was detected after treatment (Arnés et al. 2009).

In the IR group (Fig. 2), the GS $a$ activity in the muscle was lower $(0.41 \pm 0.09 \mathrm{U} / \mathrm{g}$ protein, $n=5 ; P<0.01$ vs $\mathrm{N}$-control) than that in the $\mathrm{N}$ group $(1 \cdot 80 \pm 0 \cdot 14 \mathrm{U} / \mathrm{g}$ protein, $n=5)$; treatment with both GLP-1 or Ex-4 induced a clear increase in this enzyme activity (GLP-1: $461 \pm 22 \%$ IR-control, $n=4$; Ex-4: $181 \pm 24 \%, n=6$; both, $P<0 \cdot 001$ ), which in the case of GLP-1 reached normal values. In the T2D rats, the GS $a$ activity $(1 \cdot 08 \pm$ $0 \cdot 08 \mathrm{U} / \mathrm{g}$ protein, $n=5)$, although higher than that in the IR rats, was lower than in the normal rats $(P<0 \cdot 001$ vs N-control). Although GLP-1 $(n=5)$ failed to modify the enzyme activity in this diabetic group, Ex-4 induced a trend toward its normalization $(1 \cdot 57 \pm 0 \cdot 15 \mathrm{U} / \mathrm{g}$ protein, $n=5, P<0.05$ vs $\mathrm{N}$-control).

Tables 1 and 2 show the qualitative changes in the abovementioned parameters and correspond to the

Table 1 Qualitative changes in GLUT2 ( $n=7-15$ rats) and GLUT4 ( $n=5-8)$ expression in insulin-resistant (IR) and type 2 diabetic (T2D) rats relative to normal $(N)$ animals, and effect of GLP-1 and Ex-4 treatment in relation to their respective control value (saline treated)

\begin{tabular}{ccc}
$\begin{array}{c}\text { N mRNA/ } \\
\text { protein }\end{array}$ & $\begin{array}{c}\text { IR mRNA/ } \\
\text { protein }\end{array}$ & $\begin{array}{c}\text { T2D mRNA/ } \\
\text { protein }\end{array}$ \\
\hline
\end{tabular}

$\begin{array}{lccc}\text { Liver: GLUT2 } & & & \\ \text { Control } & -/- & \downarrow / \downarrow & \downarrow / \uparrow \\ \text { GLP-1 } & \downarrow / \downarrow & \uparrow / \uparrow & \downarrow /- \\ \text { Ex-4 } & \uparrow / \uparrow & \uparrow / \uparrow & \uparrow / \uparrow \\ \text { Muscle: GLUT4 } & & & \\ \text { Control } & -/- & \uparrow / \uparrow & -/ \downarrow \\ \text { GLP-1 } & \uparrow / \downarrow & \uparrow / \uparrow & \uparrow / \uparrow \\ \text { Ex-4 } & -/ \uparrow & \uparrow / \uparrow & -/- \\ \text { Fat tissue: GLUT2 } & & & \\ \text { Control } & -/- & \downarrow /- & \downarrow / \downarrow \\ \text { GLP-1 } & \downarrow / \downarrow & -/ \uparrow & \downarrow / \uparrow \\ \text { Ex-4 } & \downarrow /- & \uparrow /- & -/ \uparrow\end{array}$

- : equal to control; $\_$and $\square$ slightly higher and lower, respectively, than control; $\uparrow$ and $\downarrow$ : significantly higher and lower, respectively, than control. 
Table 2 Glycogen content ( $n=5-12$ rats), glucose transport (GT, $n=5-12)$, and glycogen synthase a (GSa, $n=6)$ in insulinresistant (IR) and type 2 diabetic (T2D) models compared with normal rats $(N)$, and qualitative changes after GLP-1 and Ex-4 treatment with respect to their own control group (saline treated)

\begin{tabular}{|c|c|c|c|}
\hline & $\mathbf{N}$ & IR & T2D \\
\hline \multicolumn{4}{|c|}{ Liver glycogen } \\
\hline Control & - & $\downarrow$ & $\downarrow$ \\
\hline GLP-1 & - & $\uparrow$ & $\uparrow$ \\
\hline Ex-4 & - & $\uparrow$ & $\uparrow$ \\
\hline \multicolumn{4}{|c|}{ Muscle GT } \\
\hline Control & - & $\downarrow$ & - \\
\hline GLP-1 & - & $\uparrow$ & - \\
\hline Ex-4 & - & $\uparrow$ & $\uparrow$ \\
\hline \multicolumn{4}{|c|}{ Muscle GSa } \\
\hline Control & - & $\downarrow$ & $\downarrow$ \\
\hline GLP-1 & $\downarrow$ & $\uparrow$ & - \\
\hline Ex-4 & $\downarrow$ & $\uparrow$ & $\uparrow$ \\
\hline \multicolumn{4}{|c|}{ Fat tissue GT } \\
\hline Control & - & $\downarrow$ & $\uparrow$ \\
\hline GLP-1 & $\uparrow$ & $\uparrow$ & $\downarrow$ \\
\hline$E x-4$ & - & $\uparrow$ & $\downarrow$ \\
\hline
\end{tabular}

- : equal to control; $\uparrow$ and $\downarrow$ : significantly higher and lower, respectively, than control.

data contained in Fig. 2; those not shown in the figures, as for being already published, have been included in tables for comparison.

\section{Fat GLUT4 expression and GT}

Glut4 mRNA in IR (Fig. 3) was lower $(P<0 \cdot 001)$ than in normal rats $(n=8)$ while no changes were observed in the protein value; however, in the T2D group $(n=8)$, the mRNA was not significantly different from that in the $\mathrm{N}$ group, while the GLUT4 protein was lower $(P<0.05$ vs $\mathrm{N})$, the latter confirming the previous results (Villanueva-Peñacarrillo et al. 2001). Treatment of IR rats with GLP-1 did not alter the initially reduced mRNA value, but increased $(P<0 \cdot 02)$ than that of the protein $(26 \pm 5 \% \Delta$ IR-control, $n=5)$ to levels even higher than those in the $\mathrm{N}$ rats $(149 \pm 6 \% \mathrm{~N}-$ control; $P<0.001)$; in comparison with GLP-1, Ex-4 $(n=5)$ induced an increase in the Glut4 mRNA $(P<0 \cdot 05)$ to a normal expression ( $109 \pm 9 \% \mathrm{~N}$-control).

The GT value in isolated adipocytes (Fig. 3) from the IR rats $\left(8 \cdot 10 \pm 0 \cdot 49 \mathrm{fmol} / 10^{5}\right.$ cells, $\left.n=6\right)$ was lower than that in the $\mathrm{N}$ rats $\left(15 \cdot 1 \pm 1 \cdot 6 \mathrm{fmol} / 10^{5}\right.$ cells $n=12)$, while in the T2D group $(n=9)$ it was much higher $\left(45 \cdot 0 \pm 2 \cdot 7 \mathrm{fmol} / 10^{5}\right.$ cells, $P<0 \cdot 001$ vs $\left.\mathrm{N}\right)$, the latter confirming the previous observations (Sancho et al. 2005). In the IR rats, both GLP-1 and Ex-4 treatment increased $(P<0 \cdot 05)$ the GT (GLP-1: 157 $\pm 11 \%$ IR-control $n=8 ; \quad$ Ex-4: $161 \pm 11 \% \quad n=6)$; however, in T2D group, both GLP-1 and Ex-4 exerted a significantly reducing effect $(P<0 \cdot 02)$ on GT levels (GLP-1: $14.5 \pm 0.9 \mathrm{fmol} / 10^{5}$ cells $n=5$, and Ex-4:
$20 \cdot 9 \pm 1 \cdot 7 n=5$ ), by which, in the case of GLP-1, normal values were reached.

Tables 1 and 2 show the qualitative changes in the abovementioned parameters and correspond to the data contained in Fig. 3; those not shown in the figures, have been included in tables for comparison.

\section{Effect on kinases activity}

Table 3 contains the activity values of PI3K ( $\left.\mathrm{PIP}_{3}\right)$ and p44/42 MAPKs (phosphorylated form) in the liver, muscle, and fat of normal, IR, and T2D rats, treated with saline (control) or GLP-1 or Ex-4. The activity of both PI3K and p44 MAPK increased $(P<0 \cdot 02$ vs $N)$ in the liver and fat of IR-control rats, while that of $\mathrm{p} 42$ MAPK was higher than normal in the three tissues $(P<0.05$ vs $\mathrm{N})$; the same was detected in the T2D group, except for the fact that p44 MAPK in the muscle of IR rats was not different from that of the normal rats; these observations in the muscle and fat of T2D rats coincided with previous data obtained in vitro (Sancho et al. 2005, Arnés et al. 2008).

In the liver of the three groups studied, both GLP-1 and Ex-4 increased the PI3K activity (overall mean: $63 \pm 10 \% \Delta$ control, $n=34$ rats; $P<0 \cdot 001)$, and also in muscle and fat (overall mean: $57 \pm 7 \% \Delta$ control, $n=60 ; P<0 \cdot 001$ ). GLP-1 increased the initial p42 MAPK hyperactivity in the liver of IR rats further, while no effect was observed after GLP-1 treatment in the T2D group, or in the muscle and fat of the IR rats; the same was basically detected by Ex-4, except that this peptide exerted a normalizing action in the muscle and fat of IR rats $(-33 \% \Delta$ IR-control, $n=11$ ), and also on p44/42 MAPK activity in the fat tissue of T2D rats $(-38 \% \Delta \mathrm{T} 2 \mathrm{D}-$ control, $n=10)$.

\section{Discussion}

GLUT2 and GLUT4 glucotransporter isoforms play a central role in the complex pathways mediating wholebody glucose disposal, in which dysregulation of their control mechanism can result in the pathophysiological states associated with IR and diabetes.

The liver of the IR model showed a lower than normal Glut2 expression accompanied by a reduced hepatic GC also observed in liver of T2D model, the latter confirming the previous results (Arnés et al. 2009). In both experimental models, treatment with either GLP-1 or Ex-4 increased the Glut 2 expression to values even above those in normal rats; in the IR rats, this effect along with an increment in the hepatic GC to normal levels indicates an increase in the rate of glucotransporter translocation from the cytosol to the plasma membrane. GLP-1 also normalized the glycogen concentration in the T2D group, in the same manner as previously observed after Ex-4 treatment (Arnés et al. 2009). 

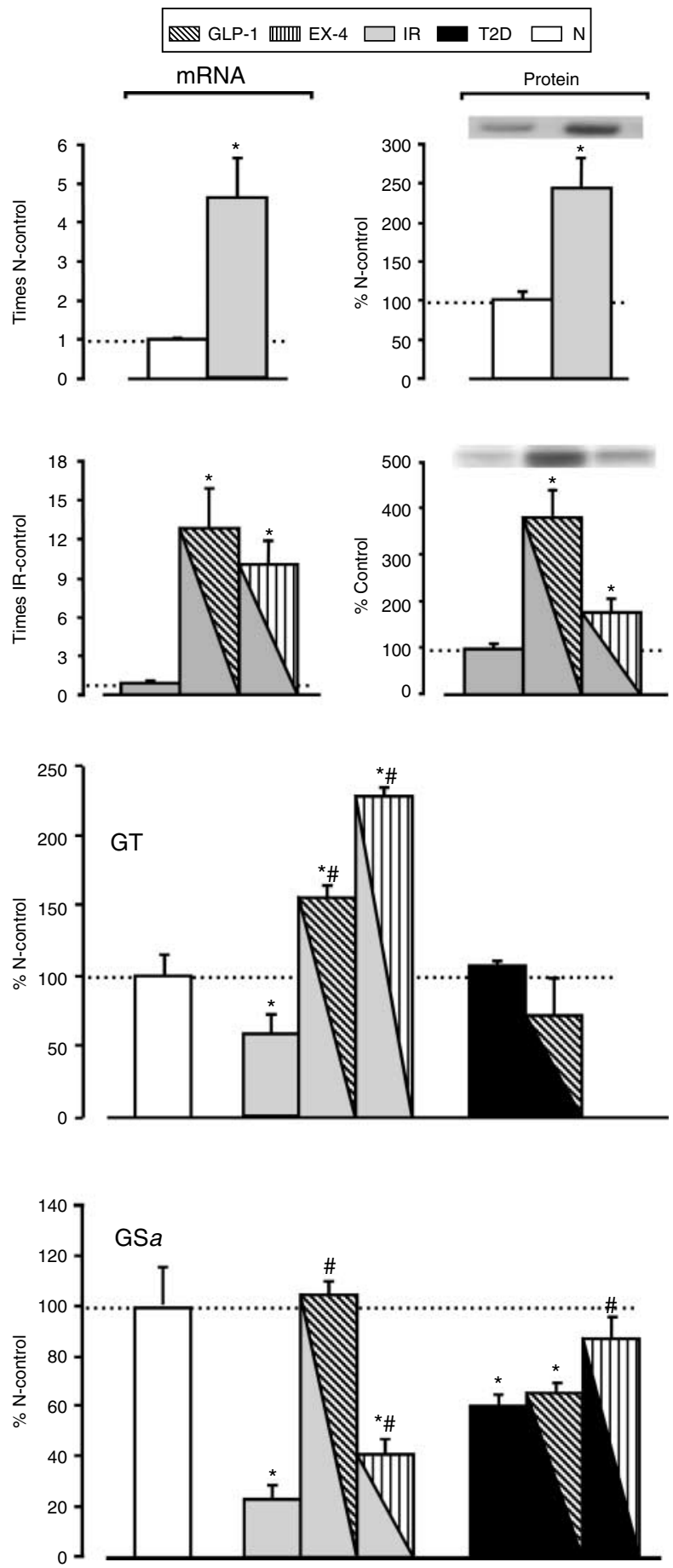

Figure 2 Effect of GLP-1 and Ex-4 treatment on Glut4 expression ( $n=5$ rats), glucose transport (GT, $n=5-10$ ), and glycogen synthase a activity (GSa, $n=6$ ) in the muscle of insulin-resistant (IR) and type 2 diabetic (T2D) rats. Data (mean \pm S.E.M.) are expressed as relative amounts (Glut4, mRNA) or percentage (GLUT4, protein, GT and GSa) of the normal (N) or respective control group (saline treated). ${ }^{*} P<0.05$, or lower, vs $\mathrm{N}$-control; ${ }^{\#} P<0.05$, or lower, vs respective control value, IR or T2D.
The present and previous results on Ex-4 support the idea of a direct effect, insulin independent, of Ex-4 on the glucose uptake and metabolism in the liver, as already suggested not only for Ex-4 but also for GLP-1 (Alcántara et al. 1997, Morales et al. 1997). Evidences from a report (Valh et al. 2007) demonstrating the presence of GLP-1 receptor in the terminal nerves of the portal vein should be taken into account; although the first step in the action of Ex-4 in the liver remains unknown, because of its homology with GLP-1, the possibility that its effects could be mediated and regulated by the central nervous system should not be discarded. These impaired values of GLUT2 and GC in the liver of IR and T2D rats were accompanied by a hyperactivation in PI3K, as a consequence, perhaps, of the development of a correcting mechanism for the former alterations; both GLP-1 and Ex-4 increased this enzyme activity even more. The latter not only confirms the importance of PI3K in the glucose metabolism of the liver (Redondo et al. 2003) but also suggests its role in restoration of the normal conditions of this tissue. In the case of MAP kinases, hyperactivated in IR and T2D, the effect of GLP-1 differed from that of Ex-4, as each showed to be targeting a different MAPK isoform, indicating a distinct mechanism of action. In fact, the insulinotropic and glucoregulatory effect of Ex- 4 has been attributed to occur through the pancreatic GLP-1 receptor (Göke et al. 1993), and based on the results obtained in a GLP-1 receptor knockout animal model, it was suggested that the pancreatic GLP-1 receptor is involved in the incretin/insulinotropic action of Ex-4 and GLP-1 and also in the hepatic portal glucose sensor action of the latter (Edwards et al. 1999, Burcelin et al. 2001). Yet, it is also known that Ex-4 displaces the GLP-1 binding to its receptors in plasma membranes of extrapancreatic tissues involved in the glucose homeostasis (Alcántara et al. 1997, Arnés et al. 2008), which are other than those in the pancreas (Thorens et al. 1993). The present observations of the liver indicate that Ex-4 can control the glucotransporter expression process and also glycogenesis, not only in normal but also in IR and T2D states, similar to GLP-1 in this study and also in a previous study on normal and diabetic rats (VillanuevaPeñacarrillo et al. 2001). The results also suggest that although other tissues could be participating, the liver seems to represent an important target organ in the glucoregulatory action of Ex-4 in states of impaired glucose homeostasis.

The observed GLUT4 overexpression in the muscle of IR rats further increased after treatment with both GLP-1 and Ex-4 and accompanied by an increase in the lower than normal glucose uptake and GS $a$ activity values, Ex-4, although stimulating the enzyme activity shown to be less efficient that GLP-1. In T2D rats, GT in the muscle was apparently indistinct from that in normal rats; yet, in a previous work performed on this 

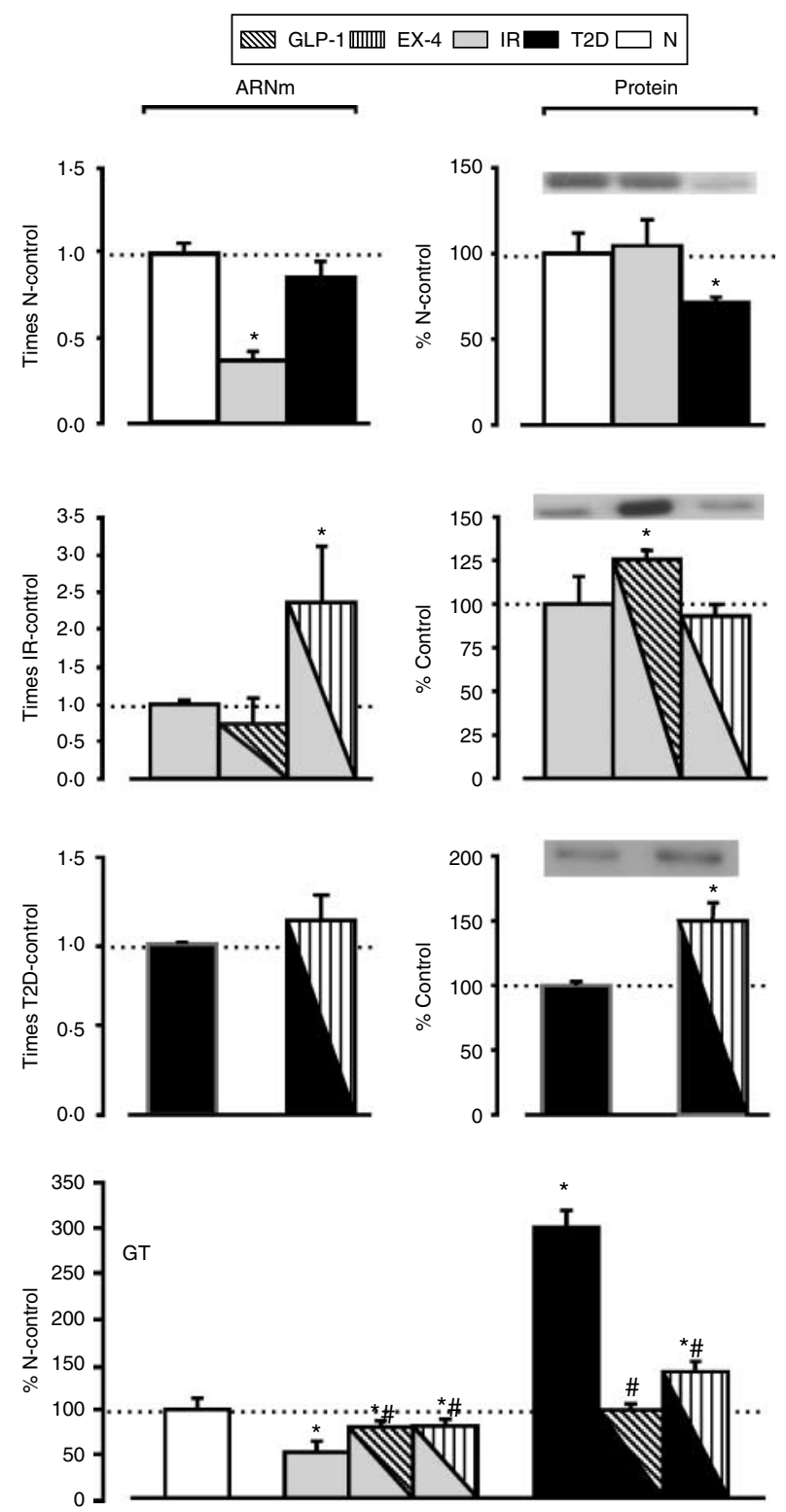

Figure 3 Effect of GLP-1 and Ex-4 treatment on fat Glut4 expression ( $n=8$ rats) and glucose transport (GT, $n=5-12$ ) in the isolated adipocytes of insulin-resistant (IR) and type 2 diabetic (T2D) rats. Data (mean \pm S.E.M.) are expressed as relative amounts (Glut4 mRNA) or percentage (GLUT4, protein and GT) of the normal ( $\mathrm{N}:)$ or respective control group (saline treated). ${ }^{\star} P<0.05$, or lower, vs $\mathrm{N}-$ control; ${ }^{\#} P<0.05$, or lower, vs respective control value, IR or T2D.

same experimental model (Arnés et al. 2009), a slightly lower than normal value was detected, coinciding with the observations in muscle cells from T2D patients (González et al. 2005b); nevertheless, the muscle GS $a$ activity also showed to be reduced. These altered values in the muscle of T2D had shown along with an apparently higher than normal levels of Glut4 mRNA, and with a slightly lower protein levels
(Villanueva-Peñacarrillo et al. 2001, Arnés et al. 2009). In the present T2D group, GLP-1 did not alter the values of GT or GS $a$ activity, while an increase in the Glut4 expression after GLP-1 treatment was previously noted (Villanueva-Peñacarrillo et al. 2001). In vitro experiments exploring the action of Ex-4 in the skeletal muscle showed no effect on GT or GS $a$ in this same T2D model (Arnés et al. 2008), Glut4 expression (Arnés et al. 2009), while in normal rats Ex-4, like GLP-1, stimulated the uptake of glucose (Arnés et al. 2008). Yet, it was noted that maintained treatment with Ex-4 induces a significant increment in glucose uptake in the muscle in T2D but not in normal animals (Arnés et al. 2009). These alterations in the muscles of the two experimental models of this study were accompanied by a lower than normal PI3K activity in the case of T2D rats, which was increased in both IR and T2D after GLP-1 or Ex-4 treatment. Also, the activity of MAPKs studied was impaired in IR and T2D, the latter confirming the previous observations (Arnés et al. 2008), each peptide, GLP-1 and Ex-4, shown to target a different isoform. The reduced PI3K activity in the muscles of T2D rats differs from previous results obtained in myocytes from T2D patients (González et al. 2005b), in which a higher than normal enzyme activity was detected, perhaps due to species differences. In fact, results from an in vitro study performed on skeletal muscle of normal rats (Acitores et al. 2005), and by using specific inhibitors for different kinases, confirmed that both PI3K and MAPKs are participating in the insulin-induced glucose uptake; yet, the role of PI3K in this same action of GLP-1 did not seem to be evident; it was demonstrated that an increment in PI3K is determinant for GLP-1, and also for Ex-4, to exert its stimulatory effect on GT and GS $a$ in rat muscles (Acitores et al. 2004, Arnés et al. 2008) and liver (Redondo et al. 2003), and also in human muscle cells (González et al. 2005a). Taken into consideration all these observations it can be said that although the skeletal muscle could be participating in the glucoregulatory action of $\mathrm{Ex}-4$, the role of this tissue in diabetic state would not be determinant.

In the fat tissue of the IR model, the downregulated Glut4 mRNA was not modified after GLP-1 treatment, while it increased the protein value above the normal, in comparison with Ex-4 which stimulated the transcriptional process without affecting the translational process; yet, both GLP-1 and Ex-4 treatment induced a normalization of the lower than normal GT. In the T2D group, Ex-4 did not alter the Glut 4 mRNA value but normalized the initially reduced protein, as previously observed after GLP-1 treatment in this same T2D model (Villanueva-Peñacarrillo et al. 2001). This altered glucotransporter expression resulted in a decrease in glucose uptake in the IR rats and an increase in the T2D rats, the latter confirming the previous results (Sancho et al. 2005); treatment with either GLP-1 or Ex-4 


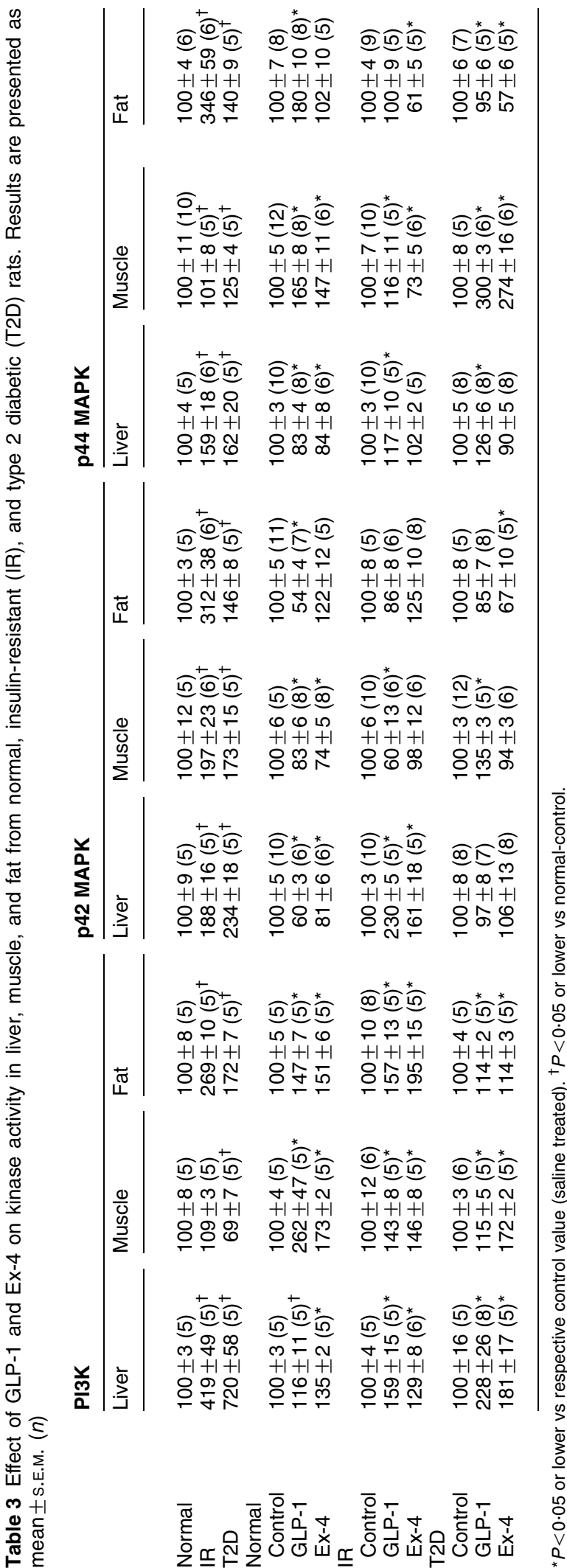

normalized the GT in both experimental models, Ex-4 being less potent in the T2D rats. Nevertheless, the observed apparent discrepancy in the fat tissue of the T2D rats, in which GLP-1 restores close to normal values of the hexose transport despite increasing the glucotransporter protein, suggests the participation of factor(s) other than GLUT4, e.g. supply of glucose as a source of metabolites for the re-esterification of fatty acids, in the regulation of GT into adipocytes. In the T2D group, the lower than normal Glut4 expression was seen along with a higher PI3K activity; in the IR group, the hyperactivity of this enzyme was accompanied by a slightly diminished glucose uptake; in both experimental models, the MAPKs activity was increased. By using specific inhibitors, the participation of PI3K and MAPKs in the stimulating effect of GLP-1, and also Ex-4, on GT and metabolism, as well as on lipid metabolism, has already been demonstrated in the adipose tissue of normal and diabetic rats (Sancho et al. 2005), and also in normal subjects (Sancho et al. 2007); in fact, an increase in the activity of both enzymes is needed not only for insulin but also for GLP-1 and Ex-4 to stimulate GT in normal human (Sancho et al. 2007) and obese patients (Sancho et al. 2006). In agreement with the latter, treatment of IR and T2D with either GLP-1 or Ex-4 clearly increased PI3K activity. The lack of effect of GLP-1 on the altered MAPK activity in either experimental model indicates that the normalizing action of GLP-1 upon Glut4 expression and GT in the adipose tissue of the T2D model is not mediated by these enzymes, and thus other mechanism could be activated in this pathological situation. In fact, it has been demonstrated that GLP-1, like insulin, Ex-4, and also its truncated form Ex-9 all stimulate not only PI3K activity but also MAPKs and p70s6k in the adipocytes of normal rats, but not $\mathrm{PKB}$, which is only increased by insulin; yet, the adipocytes of the T2D rats apparently develop a mechanism by which an increment in the activity of PKB is clearly visible when incubated with GLP-1, Ex-4, and Ex-9 (Sancho et al. 2005).

In summary, considering the results of this study as a whole, it can be asserted that the three selected extrapancreatic tissues from the IR and T2D rats were involved to a higher or lower extent in the control of glucose homeostasis exhibiting alterations in parameters related to the hexose uptake and metabolism. Also, the data demonstrate that treatment with GLP-1 or Ex-4 has a positive effect upon some of them, which results in a restoration of the normal situation in many cases, and it could justify the demonstrated glucoregulatory action of both peptides. Although Ex-4 and GLP-1 appear to share certain glucose-lowering actions, not all actions of Ex-4 are predictable based on the known pharmacology of GLP-1 (Idris et al. 2002), suggesting that Ex-4 may exert some of its effects through a functionally different receptor that is yet to be identified. 


\section{Declaration of interest}

The authors declare that there is no conflict of interest that could be perceived as prejudicing the impartiality of the research reported.

\section{Funding}

This work was supported by grants from the Instituto de Salud Carlos III (CIBERDEM, CB07/08/2007; PS09/01185), Spain. P M, A A, and I G-R are recipients of a CIBERDEM contract, and P M, B N-B, and V S were research fellows from the Fundación Conchita Rábago de Jiménez Díaz.

\section{Acknowledgements}

We thank Estrella Martín-Crespo for excellent technical assistance and Mark Davis for proofreading the manuscript.

\section{References}

Acitores A, González N, Sancho V, Valverde I \& Villanueva-Peñacarrillo ML 2004 Cell signaling of the glucagon-like peptide 1 action in rat skeletal muscle. Journal of Endocrinology 180 389-398. (doi:10.1677/ joe.0.1800389)

Acitores A, González N, Sancho V, Arnés L, Valverde I, Malaisse WJ \& Villanueva-Peñacarrillo ML 2005 Participation of protein kinases in the stimulant action of GLP-1 on 2-deoxi-D-glucose uptake by normal rat skeletal muscle. Hormone and Metabolic Research 37 275-280. (doi:10.1055/s-2005-861469)

Alcántara AI, Morales M, Delgado E, López-Delgado MI, Clemente F, Luque MA, Malaisse WJ, Valverde I \& Villanueva-Peñacarrillo ML 1997 Exendin-4 agonist and exendin (9-39) amide antagonist of the GLP-1 (7-36) amide effects in liver and muscle. Archives of Biochemistry and Biophyics 341 1-7. (doi:10.1006/abbi.1997.9951)

Arnés L, González N, Tornero-Esteban P, Sancho V, Acitores A, Valverde I, Delgado E \& Villanueva-Peñacarrillo ML 2008 Characteristics of the GLP-1 and exendins action upon glucose transport and metabolism in type 2 diabetic rat skeletal muscle. International Journal of Molecular Medicine 22 127-132.

Arnés L, Moreno P, Nuche-Berenguer B, Valverde I \& VillanuevaPeñacarrillo ML 2009 Effect of exendin-4 treatment upon glucose uptake parameters in rat liver and muscle, in normal and type 2 diabetic state. Regulatory Peptides 153 88-92. (doi:10.1016/j.regpep. 2008.08.005)

Ascencio C, Torres N, Isoard-Acosta F, Gómez-Pérez FJ, HernándezPando R \& Tovar AR 2004 Soy protein affects serum insulin and hepatic SREBP-1 mRNA and reduces fatty liver in rats. Journal of Nutrition 134 522-529.

Bak AM, Egefjord L, Gejl M, Steffensen C, Stecher CW, Smidt K, Brock B \& Rungby J 2011 Targeting amyloid-beta by glucagon-like peptide1 (GLP-1) in Alzheimer's disease and diabetes. Expert Opinion on Therapeutic Targets 15 1153-1162. (doi:10.1517/14728222.2011. 600691)

Barrera JG, D’Alessio DA, Drucker DJ, Woods SC \& Seeley RJ 2009 Differences in the central anorectic effects of glucagon-like peptide1 and exendin-4 in rats. Diabetes 58 2820-2827. (doi:10.2337/db090281)

Bradford MM 1976 A rapid and sensitive method for the quantization of microgram quantities of protein utilizing the principle of protein dye binding. Analytical Biochemistry 72 248-254. (doi:10.1016/00032697(76)90527-3)
Burcelin R, Da Costa A, Drucker D \& Thorens B 2001 Glucose competence of the hepatoportal vein sensor requires the presence of an activated glucagon-like peptide 1 receptor. Diabetes $\mathbf{5 0}$ 1720-1728. (doi:10.2337/diabetes.50.8.1720)

Cancelas J, Prieto PG, García-Arévalo M, Sancho V, VillanuevaPeñacarrillo ML, Malaisse WJ \& Valverde I 2008 Induction and reversibility of insulin resistance in rats exposed to exogenous D-fructose. Hormone and Metabolic Research 40 459-466. (doi:10. 1055/s-2008-1065318)

Chen YE \& Drucker DJ 1997 Tissue-specific expression of unique mRNAs that encode proglucagon-derived peptides or exendin 4 in the lizard. Journal of Biological Chemistry 272 4108-4115. (doi:10. 1074/jbc.272.7.4108)

Chun Y \& Yin ZD 1998 Glycogen assay for diagnosis of female genital Chlamydia trachomatis infection. Journal of Clinical Microbiology 36 1081-1082.

Delgado E, Luque MA, Alcántara A, Trapote MA, Clemente F, Galera C, Valverde I \& Villanueva-Peñacarrillo ML 1995 Glucagon-like peptide-1 binding to rat skeletal muscle. Peptides 16 225-229. (doi:10.1016/0196-9781(94)00175-8)

Dohm GL, Tapscott EB, Pories WJ, Dabbs DJ, Flickinger EG, Meelheim TF, Atkinson SM, Elton CW \& Caro JF 1988 An in vitro human muscle preparation suitable for metabolic studies. Journal of Clinical Investigation 82 486-494. (doi:10.1172/JCI113622)

Edwards CM, Todd JF, Mahmoudi M, Wang Z, Wang RM \& Ghatei M 1999 Glucagon-like peptide 1 has a physiological role in the control of postprandial glucose in humans: studies with the antagonist exendin 9-39. Diabetes 48 86-93. (doi:10.2337/diabetes.48.1.86)

Eng J, Kleinman WA, Singh L, Singh G \& Raufman JP 1992 Isolation and characterization of exendin- 4 , an exendin- 3 analogue, from Heloderma suspectum venom. Further evidence for an exendin receptor on dispersed acini from guinea pig pancreas. Journal of Biological Chemistry 15 7402-7405.

Fineman MS, Bicsak TA, Shen LZ, Taylor K, Gaines E, Varns A, Kim D \& Baron AD 2003 Effect on glycemic control of exenatide (synthetic exendin-4) additive to existing metformin and/or sulfonylurea treatment in patients with type 2 diabetes. Diabetes Care 26 2370-2377. (doi:10.2337/diacare.26.8.2370)

Göke R, Fehmann HC, Linn T, Schmidt H, Krause M \& Eng J 1993 Exendin-4 is a high potency agonist and truncated exendin-(9-39) amide an antagonist at the glucagon-like peptide 1 (7-36)-amide receptor of insulin-secreting $\beta$-cells. Journal of Biological Chemistry 268 19650-19655.

González N, Acitores A, Sancho V, Valverde I \& Villanueva-Peñacarrillo ML $2005 a$ Effect of GLP-1 on glucose transport and its cell signalling in human myocytes. Regulatory Peptides 126 203-211. (doi:10.1016/j.regpep.2004.10.002)

González N, Sancho V, Martin-Duce A, Tornero-Esteban P, Valverde I, Malaisse WJ \& Villanueva-Peñacarrillo ML $2005 b$ GLP-1 signalling and effects on glucose metabolism in myocytes from type 2 diabetic patients. International Journal of Molecular Medicine $\mathbf{1 6}$ $747-752$.

Herbert V, Lau KS, Goltlieb CW \& Bleicher SJ 1956 Coated charcoal inmunoassay of insulin. Journal of Clinical Investigation 25 1375-1384.

Hotamisligil GS 2000 Molecular mechanism of insulin resistance and the role of the adipocyte. International Journal of Obesity 24 S23-S27. (doi:10.1038/sj/ijo/0801497)

Idris I, Patiag D, Gray S \& Donelly R 2002 Exendin-4 increases insulin sensitivity via a PI-3-kinase-dependent mechanism: contrasting effects of GLP-1. Biochemical Pharmacology 63 993-996. (doi:10.1016/ S0006-2952(01) 00924-8)

Iwase M, Kikuchi M, Nunoi K, Wakisaka M, Maki Y, Sadoshima S \& Fujishima M 1987 Blood pressure changes in spontaneously hypertensive and normotensive rats with neonatal streptozotocine induced type 2 diabetes. Clinical and Experimental Hypertension. Part A, Theory and Practice 9 2157-2168. (doi:10.3109/106419687 09159081) 
Laemmli UK 1970 Cleavage of structural proteins during the assembly of the head of bacteriophage T4. Nature 227 680-685. (doi:10.1038/ $227680 \mathrm{a} 0$ )

Luque MA, González N, Márquez L, Acitores A, Redondo A, Morales M, Valverde I \& Villanueva-Peñacarrillo ML 2002 GLP-1 and glucose metabolism in human myocytes. Journal of Endocrinology 173 465-473. (doi:10.1677/joe.0.1730465)

Morales M, López-Delgado MI, Alcántara A, Luque MA, Clemente F, Márquez L, Puente J, Viñambres C, Malaisse WJ, VillanuevaPeñacarrillo ML et al. 1997 Preserved GLP-1 effects on glycogen synthase a activity and glucose metabolism in isolated hepatocytes and skeletal muscle from diabetic rats. Diabetes 46 1264-1269. (doi:10.2337/diabetes.46.8.1264)

Nielsen LL, Young AA \& Parkes DG 2004 Pharmacology of exenatide (synthetic exedin-4): a potential therapeutic for improved glycemic control of type 2 diabetes. Regulatory Peptides 117 77-88. (doi:10. 1016/j.regpep.2003.10.028)

Nuche-Berenguer B, Moreno P, Esbrit P, Dapía S, Caeiro JR, Cancelas J, Haro-Mora JJ \& Villanueva-Peñacarrillo ML 2009 Effect of GLP-1 treatment on bone turnover in normal, type 2 diabetic, and insulinresistant states. Calcified Tissue International 84 453-461. (doi:10. 1007/s00223-009-9220-3)

Nuche-Berenguer B, Moreno P, Portal-Nuñez S, Dapía S, Esbrit P \& Villanueva-Peñacarrillo ML $2010 a$ Exendin-4 exerts osteogenic actions in insulin-resistant and type 2 diabetic states. Regulatory Peptides 159 61-66. (doi:10.1016/j.regpep.2009.06.010)

Nuche-Berenguer B, Portal-Nuñez P, González N, Acitores A, López A Herrado N, Esbrit P, Valverde I \& Villanueva-Peñacarrillo ML $2010 b$ Presence of a functional receptor for GLP-1 in osteoblastic cells, independent of the cAMP-liked GLP-1 receptor. Journal of Cellular Physiology 225 585-592. (doi:10.1002/jcp.22243)

Nuche-Berenguer B, Lozano D, Gutiérrez-Rojas I, Moreno P, Mariñoso ML, Esbrit P \& Villanueva-Peñacarrillo ML 2011 GLP-1 and exendin-4 can reverse hyperlipidic-related osteopenia. Journal of Endocrinology 209 203-210. (doi:10.1530/JOE-11-0015)

Ossum A, van Deurs U, Engstrom T, Jensen SS \& Treiman M 2009 The cardioprotective and inotropic components of the postconditioning effects of GLP-1 and GLP-1 (9-36) a in an isolated rat heart. Pharmacological Research 60 411-417. (doi:10.1016/j.phrs.2009.06.004)

Perea A, Viñambres C, Clemente F, Villanueva-Peñacarrillo ML \& Valverde I 1997 GLP-1 (7-36) amide: effects on glucose transport and metabolism in rat adipose tissue. Hormone and Metabolic Research 29 417-421. (doi:10.1055/s-2007-979068)

Phung TL, Roncone A, Jensen KL, Sparks CE \& Sparks JD 1997 Phosphoinositide 3-kinase activity is necessary for insulin-dependent inhibition of apolipoprotein B secretion by rat hepatocytes and localizes to the endoplasmic reticulum. Journal of Biological Chemistry 272 30693-30702. (doi:10.1074/jbc.272.49.30693)

Portha B, Picon L \& Rosselin G 1979 Chemical diabetes in the adult rat as the spontaneous evolution of neonatal diabetes. Diabetologia $\mathbf{1 7}$ 371-377. (doi:10.1007/BF01236272)

Redondo A, Trigo V, Acitores A, Valverde I \& Villanueva-Peñacarrillo ML 2003 Cell signaling of the GLP-1 action in rat liver. Molecular and Cellular Endocrinology 204 43-50. (doi:10.1016/S0303-7207(03) 00146-1)

Rodbell M 1964 Metabolism of isolated fat cells. I. Effects of hormones on glucose metabolism and lipolysis. Journal of Biological Chemistry 239 375-380.

Sancho V, Trigo MV, González N, Valverde I, Malaisse WJ \& VillanuevaPeñacarrillo ML 2005 Effects of GLP-1 and exendins on kinase activity, 2-deoxy-D-glucose transport, lipolysis and lipogenesis in adipocytes from normal and streptozotocine induced type 2 diabetic rats. Journal of Molecular Endocrinology 35 27-38. (doi:10. $1677 /$ jme.1.01747)

Sancho V, Trigo MV, Martín-Duce A, González N, Acitores A, Arnés L, Valverde I, Malaisse WJ \& Villanueva-Peñacarrillo ML 2006 Effect of GLP-1 on D-glucose transport, lypolisis and lipogenesis in adipocytes of obese subjects. International Journal of Molecular Medicine 17 1133-1137.
Sancho V, Nuche B, Arnés L, Cancelas J, González N, Díaz-Miguel M, Martín-Duce A, Valverde I \& Villanueva-Peñacarrillo ML 2007 The action of GLP-1 and exendins upon glucose transport in normal human adipocytes, and on kinase activity as compared to morbidly obese patients. International Journal of Molecular Medicine 19 961-966.

Sanz C, Vázquez P, Blázquez C, Barrio PA, Álvarez MM \& Blázquez E 2010 Signaling and biological effects of glucagon-like peptide 1 on the differentiation of mesenchymal stem cells from human bone marrow. American Journal of Physiology. Endocrinology and Metabolism 298 E634-E643. (doi:10.1152/ajpendo.00460.2009)

Talsania T, Anini Y, Siu S, Drucker DJ \& Brubaker PL 2005 Peripheral exendin-4 and peptide YY (3-36) synergistically reduce food intake through different mechanisms in mice. Endocrinology 146 3748-3756. (doi:10.1210/en.2005-0473)

Thorens B 1992 Expression clonning of the pancreatic beta-cell receptor for the glucoincretin hormone glucagon-like peptide-1. PNAS 89 8641-8645. (doi:10.1073/pnas.89.18.8641)

Thorens B, Porret A, Bühler L, Deng SP, Morel P \& Widmann C 1993 Cloning and functional expression of the human islet GLP-1 receptor: demonstration that exendin- 4 is an agonist and exendin (9-39) an antagonist of the receptor. Diabetes 42 1678-1682. (doi:10. 2337/diabetes.42.11.1678)

Tourrel C, Bailbe D, Lacorne M, Meile MJ, Kergoat M \& Portha B 2002 Persistent improvement of type 2 diabetes in the Goto-Kakizaki rat model by expansion of the beta-cell mass during the prediabetic period with glucagon-like peptide-1 or exendin-4. Diabetes $\mathbf{5 1}$ 1443-1452. (doi:10.2337/diabetes.51.5.1443)

Valh TP, Tauchi M, Durler TS, Elfers EE, Fernandes TM, Bitner RD, Ellis KS, Woods SC, Seeley RJ, Herman JP et al. 2007 Glucagon-like peptide-1 (GLP-1) receptors expressed on nerve terminals in the portal vein mediate the effects of endogenous GLP-1 on glucose tolerance in rats. Endocrinology 148 4965-4973. (doi:10.1210/en. 2006-0153)

Valverde I, Barreto M \& Malaisse WJ 1988 Stimulation by D-glucose of protein biosynthesis in tumoral insulin-producing cells (RINm5F line). Endocrinology 122 1443-1448. (doi:10.1210/endo-122-4-1443)

Valverde I, Morales M, Clemente F, López-Delgado MI, Delgado E, Perea A \& Villanueva-Peñacarrillo ML 1994 Glucagon-like peptide1: a potent glycogenic hormone. FEBS Letters 349 313-316. (doi:10. 1016/0014-5793(94)00699-7)

Villanueva-Peñacarrillo ML, Alcántara A, Clemente F, Delgado E \& Valverde I 1994 Potent glycogenic effect of GLP-1 (7-36) amide in rat skeletal muscle. Diabetologia 37 1163-1166. (doi:10.1007/ BF00418382)

Villanueva-Peñacarrillo ML, Delgado E, Trapote MA, Alcántara A, Clemente F, Luque MA, Perea A \& Valverde I 1995 Glucagon-like peptide-1 binding to rat hepatic membranes. Journal of Endocrinology 146 183-189. (doi:10.1677/joe.0.1460183)

Villanueva-Peñacarrillo ML, Puente J, Redondo A, Clemente F \& Valverde I 2001 Effect of GLP-1 treatment on GLUT-2 and GLUT-4 expression in type 1 and type 2 rat diabetic models. Endocrinology 15 241-248.

Willms B, Werner J, Holst JJ, Orskov C, Creutzfeldt W \& Nauck MA 1996 Gastric emptying, glucose responses, and insulin secretion after a liquid test meal: effects of exogenous glucagon-like peptide-1 (GLP-1)-(7-36) amide in type 2 (noninsulindependent) diabetic patients. Journal of Clinical Endocrinology and Metabolism 81 327-332. (doi:10.1210/jc.81.1.327)

Zierath JR, Krook A \& Wallberg-Henriksson H 2000 Insulin action and insulin resistance in human skeletal muscle. Diabetologia 43 821-835. (doi:10.1007/s001250051457)

Received in final form 13 October 2011

Accepted 7 November 2011

Made available online as an Accepted Preprint 7 November 2011 